Jurnal Professional FIS UNIVED Vol. 4 No. 2 Desember 2017

\title{
FUNGSI KEHUMASAN BADAN PERPUSTAKAAN PROVINSI BENGKULU DALAM MENINGKATKAN MINAT KUNJUNG DAN GEMAR MEMBACA
}

\author{
Oleh: \\ SEPTA AGUSTINA \\ Program Studi S2 Ilmu Komunikasi FISIP Universitas Bengkulu
}

\begin{abstract}
This study aims to determine the " Field Service Strategy ( PR function ) Library Board of Bengkulu province in increasing interest and love reading itinerant ", as well as to know the constraints faced by the field service visits increase interest in and love to read. This study uses the concept of management " process four main stages " of Scot M.Cutlip and Allen H. The Center for Research and Listening, Planning and Decision Makers, Communicating and Implementation ,Assessment . Data collection in this study used interview techniques, observation, documentation and literature. Key informant interviews were conducted to the local library service field staff, and the principal informant visitors who visit the library. Analyzed using qualitative data through the stages of data reduction, data display, conclusion. The results showed that (1) the service area of the library board strategy Bengkulu province in increasing interest and love reading visit is to establish the village library and adds library collection materials each year . (2) The contents of the messages used Bengkulu library service areas are invited to have a love reading because the reading will add to the knowledge and window to the world . ( 3 ) the implementation of media strategies that used the local library is not maximized because it is constrained by limited funding . As for the major constraint in increasing interest and love reading go by the library staff is limited funding.
\end{abstract}

Keywords : PR strategy, technique of communication, reading, library board Bengkulu province

\section{PENDAHULUAN}

Meningkatkan minat baca masih merupakan pekerjaan rumah yang belum terselesaikan bagi bangsa Indonesia. Berbagai program seperti perpustakaan keliling dan koran desa telah dilakukan untuk meningkatkan minat baca masyarakat. Pemerintah, praktisi pendidikan, LSM dan masyarakat yang peduli pada kondisi minat baca saat ini telah melakukan berbagai kegiatan yang diharapkan mampu meningkatkan apresiasi masyarakat untuk membaca, akan tetapi berbagai programtersebut belum memperoleh hasil maksimal. Perkembangan teknologi informasi di Indonesia ternyata tidak serta merta memberikan pengaruh positif bagi seluruh dimensi kehidupan masyarakat. Salah satu hal belum bertumbuh seiring perkembangan teknologi informasi tersebut adalah pertumbuhan minat baca. Warta Online, 26 Januari 2011 merilis Survei UNESCO (United Nations 
Educational, Scientific and Cultural Organization) menunjukkan bahwa minat baca masyarakat yang paling rendah di ASEAN (Association of Southeast Asian Nations) adalah Indonesia berada pada peringkat ke-60 di dunia. Rendahnya minat baca ini dibuktikan dengan indeks membaca masyarakat Indonesia yang baru sekitar $0,01 \%$, dari sepuluh ribu orang Indonesia hanya 1 orang saja yang memiliki minat baca tinggi. Angka ini masih sangat jauh dibandingkan dengan angka minat baca di Negara Singapura yang memiliki indeks membaca sampai 55 persen.

Jika berbicara mengenai minat membaca, maka erat kaitannya dengan perpustakaan, dan tidak mungkin berbicara tentang perpustakaan tanpa berbicara tentang buku. Seiring dengan perkembangan zaman dan berkembangnya jumlah penduduk maka perpustakaan pun juga mengalami perkembangan. Hanya saja seperti kita ketahui bahwa dizaman teknologi canggih ini, perpustakaan terkadang belum menjadi tempat yang nyaman untuk sebagian masyarakat.

Sebagaimana halnya di Bengkulu juga menunjukkan masih rendahnya minat membaca terhadap buku-buku yang ada di perpustakaan. Dilihat dari jumlah pengunjung perpustakaan pada bulan Januari mencapai 20 - 30 orang per hari dan pada bulan februari - Maret pengunjung mencapai 28 - 50 orang per hari, jika dibandingkan dengan jumlah penduduk Provinsi Bengkulu sebesar 1.766.794 jiwa (Sumber berdasarkan Sensus Penduduk).

Merujuk pada publikasi IAEEA tanggal 28 November 2007 tentang minat baca, dari 41 negara kemampuan membaca siswa Indonesia setingkat dengan negara belahan bagian selatan dengan Selandia Baru dan Afrika Selatan.
Sedangkan BPS (Badan Pusat Statistik) tahun 2006 mempublikasikan, membaca bagi masyarakat Indonesia belum menjadikan kegiatan sebagai sumber untuk mendapatkan informasi. Masyarakat lebih memilih menonton televisi (85,9\%) dan mendengarkan radio (40,3\%) daripada membaca (23,5\%). Artinya, membaca untuk mendapatkan informasi baru dilakukan oleh $23,5 \%$ dari total penduduk Indonesia, mengingat kultur orang Indonesia lebih suka mendengarkan dan berbicara bukan membaca.

Dengan melihat keadaan tersebut, maka perpustakaan daerah Bengkulu sebagai lembaga yang mengatur, dan menjalankan misi pemerintah memiliki peran penting dalam mencerdaskan masyarakat melalui membaca untuk meningkatkan ilmu pengetahuan. Maka untuk mensosialisasikan peran dan fungsi perpustakaan sangat dibutuhkan divisi humas. Humas membentuk sebuah komunikasi yang baik terhadap khalayak luarnya agar menghasilkan hubungan yang harmonis antara organisasi/perusahaan dengan khalayak publik/sasarannya. Dalam fungsi kehumasannya, perpustakaan daerah Bengkulu tidak memiliki struktur kehumasan dan menjalankan kehumasan dengan Technique of Communication. Berdasarkan definisi International Public Relation Association ( IPRA) menyatakan bahwa hubungan masyarakat adalah fungsi manajemen. Ini menunjukkan jika humas bukan alat yang diadakan, dipindahkan melainkan fungsi yang melekat menjadi satu dengan manajemen. Di mana ada manajemen, disitu ada hubungan masyarakat dan daya yang menggerakkan serta menjalankan hubungan masyarakat adalah komunikasi.

Sampai saat ini perpustakaan masih belum menjadi salah satu tempat yang 
Jurnal Professional FIS UNIVED Vol. 4 No. 2 Desember 2017

digemari untuk dikunjungi oleh masyarakat, "perpustakaan kebanyakan dikunjungi mahasiswa paling untuk keperluan mencari tugas dan literatur saja, itu pun jika koleksi buku yang dicari ada, ataupun sekedar wifi-an"( wawancara dengan kepala sub bidang layanan Neng Neni). Oleh sebab itu dirasakan sangat perlu strategi dalam meningkatkan minat kunjung dan gemar membaca masyarakat.

Berangkat dari apa yang telah diuraikan tersebut, penulis tertarik untuk mengkaji bagaimana fungsi kehumasan perpustakaan daerah Provinsi Bengkulu dalam meningkatkan minat kunjung baca masyarakat di Kota Bengkulu.

Adapun tujuan penelitian ini yaitu:

1. Untuk menjelaskan Fungsi kehumasan Perpustakaan Provinsi Bengkulu dalam meningkatkan minat kunjung dan gemar membaca.

2. Untuk mengetahui dan menjelaskan kendala yang dihadapi bidang layanan/humas perpustakaan Provinsi Bengkulu dalam meningkatkan minat kunjung dan gemar membaca.

\section{METODE PENELITIAN}

Penelitian ini menggunakan metode pendekatan deskriptif kualitatif yakni ingin mengetahui gambaran fungsi kehumasan pada Badan Perpustakaan Provinsi Bengkulu dalam meningkatkan minat kunjung dan gemar membaca.

\section{Objek Penelitian dan Fokus Penelitian}

Dalam penelitian ini, yang menjadi objek penelitian adalah Badan Perpustakaan Provinsi Bengkulu dimana subjek penelitian adalah staf perpustakaan yang mengetahui strategi yang dilakukan dalam meningkatkan minat kunjung dan gemar membaca serta pengunjung perpustakaan yang mengunjungi perpustakaan.

\section{Teknik Pengumpulan Data}

Teknik pengumpulan data yang dilakukan adalah data primer melalui observasi, wawancara dan dokumentasi, sedangkan data sekunder menggunakan studi kepustakaan.

\section{Teknik Analisis Data}

Untuk menganalisis data dalam penelitian ini menggunakan konsep Miles dan Huberman dimana dalam analisis ini dilakukan secara interaktif dan berlangsung secara terus menerus pada setiap tahap penelitian sampai tuntas dan datanya sampai jenuh.

\section{Keabsahan Data}

Keabsahan data yang digunakan oleh peneliti dengan menggunakan triangulasi sumber dan metode.

\section{HASIL PENELITIAN DAN PEMBAHASAN}

Penelitian ini bertujuan untuk mengetahui strategi bidang layanan Perpustakaan Provinsi Bengkulu dalam meningkatkan minat kunjung dan gemar membaca. Perpustakaan Provinsi Bengkulu tidak memiliki struktur kehumasan yang tergambar dengan ruangan/divisi (state of being), Perpustakaan Provinsi Bengkulu menjalankan kehumasan dengan technique of communication dimana kegiatan humas dilakukan oleh setiap bagian atau bidang lainnya. Meskipun perpustakaan daerah Provinsi Bengkulu tidak memiliki struktur kehumasan, perpustakaan tetap berusaha menjaga citra dikalangan masyarakat/pengunjung melalui bidang layanan karena bidang layanan ini merupakan tolak ukur dalam memberikan reputasi yang baik terhadap khalayak 
ramai. Dalam hal ini, untuk meningkatkan minat kunjung dan gemar membaca, perpustakaan memiliki bidang perencanaan dan pelaporan ( dalam hal ini menjalankan fungsi kehumasan) berkoordinasi dengan bidang layanan dalam meningkatkan minat kunjung dan gemar membaca. Berkaitan dengan seperti apa strategi bidang layanan dalam meningkatkan minat kunjung dan gemar membaca, ada beberapa kegiatan yang dilakukan oleh pihak Perpustakaan daerah Provinsi Bengkulu dalam melakukan program gemar membaca. Salah satunya dengan membentuk perpustakaan desa di setiap kelurahan di beberapa kabupaten yang ada di Provinsi Bengkulu, dan hingga saat ini program perpustakaan desa sudah mencapai 300 perpustakaan. Selain itu pihak perpustakaan juga memiliki perpustakaan keliling agar dapat mencapai daerah-daerah pelosok.

Berdasarkan hasil data yang diperoleh melalui observasi, wawancara peneliti menetapkan 4 informan kunci yang terdiri dari staf Perpustakaan dan informan pokok terdiri dari 3 orang.

\section{Pembahasan}

Menurut Scott M. Cutlip, Allen H. Center dan Glen M. Broom (Ruslan, 2007 :25), definisi PR adalah fungsi manajemen yang menilai sikap-sikap publik, mengidentifikasikan kebijakankebijakan dan prosedur-prosedur dari individu atau organisasi atas dasar kepentingan publik dan melaksanakan rencana kerja untuk memperoleh pengertian dan pengakuan publik. Sementara menurut Denny Griswold ( Ardianto,2011:9) Humas adalah fungsi manajemen yang mengevaluasi publik, memperkenalkan berbagai kebijakan dan prosedur dari suatu individu atau organisasi berdasarkan kepentingan publik, dan membuat perencanaan, serta melaksanakan suatu program kerja dalam upaya memperoleh pengertian dan pengakuan publik.

Bidang layanan perpustakaan daerah Provinsi Bengkulu dalam meningkatkan minat kunjung tidak membatasi masyarakat yang ingin berkunjung ke perpustakaan. Mengingat memang perpustakaan sebagai tempat masyarakat dalam mendapatkan pengetahuan sehingga sasaran/khalayak meliputi seluruh lapisan masyarakat. Bidang layanan sebagai wakil dari instansi dalam menjalin komunikasi dengan khalayak juga memiliki strategi dalam meningkatkan minat kunjung melalui proses aspek dan manajemen konsep perencanaan program kerja Scot M. Cutlip.

Berdasarkan ulasan diatas, Perpustakaan daerah Provinsi Bengkulu mampu mengelola manajemen dengan baik yang mana program dan event-event yang digelar sesuai dengan tujuan mereka dapat dilaksanakan secara efektif dan efisien begitu juga dalam proses manajemen konsep Scot M. Cutlip yang dilakukan oleh pihak perpustakaan daerah Provinsi Bengkulu dalam mencapai kegiatan program kerja, namun tidak semua konsep perencanaan ini diaplikasikan penuh oleh Perpustakaan Provinsi Bengkulu, dikarenakan ada beberapa hal yang dihadapi oleh pihak Perpustakaan daerah Provinsi Bengkulu.

Dalam proses aspek manajemen suatu instansi, tidak semua program kerja bisa berjalan dengan lancar. Begitu pula badan perpustakaan Provinsi Bengkulu dalam meningkatkan minat kunjung dan gemar membaca, bidang layanan dan perencanaan badan Perpustakaan Provinsi Bengkulu juga mengalami kendala, Dalam melakukan suatu proses perencanaan, perpustakaan Provinsi Bengkulu 
dihadapkan pada beberapa kendala yang dihadapi yaitu kendala dari dalam (karyawan) maupun dari luar. Dari hasil evaluasi yang telah dilakukan berbagai faktor atau kendala dalam meningkatkan minat kunjung dan gemar membaca adalah terbatasnya anggaran yang didapatkan oleh pihak instansi dari pemerintah Provinsi Bengkulu. Tetapi tidak hanya itu, berdasarkan pengamatan yang dilakukan oleh peneliti bukan hanya dana yang sebenarnya menjadi halangan terbesar untuk meningkatkan minat kunjung dan gemar membaca melainkan juga terlihat dari internalnya sendiri. Ketika pengunjung sedang asyik mencari bahan koleksi ataupun sedang membaca, karyawan lainnya duduk dan mengobrol diruang koleksi tanpa mengindahkan pengunjung yang membaca bahkan ada pula pengunjung yang ingin mengembalikan buku atau meminjam terkadang petugas tidak ada ditempat. Maka hal ini juga menjadi salah satu faktor tingkat pengunjung rendah karena pengunjung merasa kurang nyaman dengan keadaan ini, sehingga dalam pengamatan yang dilakukan peneliti bahwa bidang layanan perlu melakukan tingkat disiplin bagi karyawan untuk meningkatkan kualitas pelayanan.

\section{PENUTUP}

\section{Kesimpulan}

Berdasarkan pembahasan yang telah dibahas sebelumnya, dapat disimpulkan bahwa strategi yang dilakukan bidang layanan dalam fungsi kehumasan Badan Perpustakaan Provinsi Bengkulu dalam meningkatkan minat kunjung dan gemar membaca adalah sebagai berikut :
1. Melakukan
pembentukan
perpustakaan desa yang ada
diseluruh Provinsi Bengkulu dan
menggelar mobil perpustakaan

keliling keseluruh tempat yang tidak terjangkau. Ada pula dalam meningkatkan minat kunjung perpustakaan, bidang layanan menggunakan strategi seperti peningkatan jumlah bahan koleksi pustaka yang diperbarui setiap tahunnya, fasilitas internet dan menggelar pameran buku.

2. Kendala yang dihadapi Badan Perpustakaan Provinsi Bengkulu dalam meningkatkan minat kunjung dan gemar membaca adalah dana yang terbatas dan juga faktor dari internal instansi itu sendiri.

3. Meskipun tidak memiliki struktur kehumasan, Badan Perpustakaan Provinsi Bengkulu menggunakan humas sebagai Technicque of Communication.

\section{Saran}

1. Berdasarkan temuan-temuan penelitian maka perlu diadakan riset mengenai minat baca, apalagi memang untuk kota Bengkulu sendiri masih kurang dalam mengunjungi perpustakaan.

2. Untuk bidang layanan perpustakaan diharapkan dapat menambah keberagaman jumlah koleksi bahan pustaka .

3. Disarankan untuk badan perpustakaan provinsi Bengkulu khususnya bidang layanan dapat lebih meningkatkan lagi kualitas pelayanan terhadap pengunjung perpustakaan.

4. Dalam meningkatkan minat kunjung dan gemar membaca hendaknya badan perpustakaan Provinsi Bengkulu dapat memanfaatkan media massa dalam mempromosikan perpustakaan serta melaksanakan implementasi melalui program acara 
Jurnal Professional FIS UNIVED Vol. 4 No. 2 Desember 2017

seperti mengadakan talkshow
mengenai minat baca sehingga
masyarakat akan tahu betapa
pentingnya gemar membaca bagi
seseorang.

\section{DAFTAR PUSTAKA}

Anggoro, M Linggar. 2002. Teori dan Profesi Kehumasan. Jakarta : Bumi Aksara.

Ardianto, Elvinaro. 2011. Handbook of Public Relation Pengantar Komprehensif. Bandung : Simbiosis Rekatama Media.

Coulson-Thomas, Colin. 2002. Public Relations : Pedoman Praktis untuk $P R$ / Colin Coulson-Thomas; penerjemah Lucas Ginting. Jakarta : Bumi Aksara.

Effendi, Onong Uchajana. 2006. Ilmu Komunikasi : Teori dan Praktik. Bandung : Remaja Rosdakarya.

Emzir. 2010. Metodologi Penelitian Kualitatif Analisis Data. Jakarta : Rajawali Pers. 